This item was submitted to Loughborough's Research Repository by the author.

Items in Figshare are protected by copyright, with all rights reserved, unless otherwise indicated.

\title{
Exploring internal organisational communication dynamics in the professional football industry
}

PLEASE CITE THE PUBLISHED VERSION

https://doi.org/10.1108/EJM-05-2019-0422

\section{PUBLISHER}

Emerald

VERSION

AM (Accepted Manuscript)

\section{PUBLISHER STATEMENT}

This author accepted manuscript is deposited under a Creative Commons Attribution Non-commercial 4.0 International (CC BY-NC) licence. This means that anyone may distribute, adapt, and build upon the work for non-commercial purposes, subject to full attribution. If you wish to use this manuscript for commercial purposes, please contact permissions@emerald.com

\section{LICENCE}

CC BY-NC 4.0

\section{REPOSITORY RECORD}

Manoli, Elisavet, and lan Hodgkinson. 2021. "Exploring Internal Organisational Communication Dynamics in the Professional Football Industry”. Loughborough University. https://hdl.handle.net/2134/14597421.v1. 


\title{
Exploring internal organisational communication dynamics in the professional football industry
}

Submitted to: European Journal of Marketing

\author{
Argyro Elisavet Manoli ${ }^{1}$ \\ (Corresponding Author) \\ School of Sport, Exercise and Health Sciences \\ Loughborough University \\ Email: E.A.Manoli@lboro.ac.uk
}

Ian R. Hodgkinson ${ }^{2}$

School of Business and Economics

Loughborough University

Email: I.R.Hodgkinson@lboro.ac.uk

${ }^{1}$ School of Sport, Exercise and Health Sciences, Loughborough University, Leicestershire LE11 3TU, UK. Tel: +44 (0)1509 228453.

${ }^{2}$ School of Business and Economics, Loughborough University, Leicestershire LE11 3TU, UK. Tel: +44 (0)1509223865. 


\title{
Exploring internal organisational communication dynamics in the professional football industry
}

\begin{abstract}
Purpose: Relative to the increasing focus on organisations' outward communication consistency and coherency, the internal communication taking place between different organisational functions is under-explored. The study addresses two research questions: (1) What form does cross-functional communication take within organisations? (2) How do features of the communication work climate influence the form of cross-functional communication?

Design: The study draws on qualitative data generated from semi-structured interviews with media and marketing managers from 33 professional football organisations operating in the English Premier League.

Findings: Thematic patterns between internal communication practices and different communication climates lead to the development of a new internal organisational communications typology, comprising: Type 1: Collaborative symmetrical communication (Cohesive climate); Type 2: Unstructured informal communication (Friendly climate); and, Type 3: Cross-functional silos (Divisive climate).

Originality/value: Internal organisational communication practices are deemed fundamental to organisational success, yet there remains limited empirical evidence of the form such practices take or how they interact with features of an organisation's communication climate. The study introduces a new internal organisational communications typology to develop and extend the theory and practice of internal marketing communications.

Keywords Cross-functional communication; communication climate; organisational communication; internal communication; English Premier League.
\end{abstract}




\section{Introduction}

In the modern marketing environment, there is an increasing focus on organisations' outward marketing communication practices and messages (Kenyon, Manoli \& Bodet, 2018). How these outward communications and marketing messages are being designed, planned and executed internally within organisations, however, seems to receive disproportional consideration despite consensus of the value internal communication can generate (e.g. Andersson, 2019). Indeed, the importance of effective internal communication is widely accepted, and hard to contest as both a prerequisite for organisational success (Men, 2014) and a core competency of the firm (Andersson, 2019), but the form that internal communication takes in practice remains a 'blackbox’ (e.g. Andersson, 2019; Forward, Czech, \& Lee, 2011; Welch \& Jackson, 2007).

When internal communication has been examined, the wider marketing and communications literature has primarily focused on line management communication such as supervisor to subordinate, or in the context of small-group projects and team task discussions (Grunig, Grunig \& Ehling, 1992; Malhotra and Ackfeldt, 2016; Men, 2014). Yet, as Malhotra and Ackfeldt (2016) highlight, it is also critical to study internal organisational communication, which has received far less scholarly attention. Welch and Jackson (2007) provide one exception in their conceptualisation of internal corporate communication, which represents the highest level of the internal communication matrix (cf. Malhotra and Ackfeldt, 2016). However, this is just one form of internal organisational communication, characterised as vertical and top-down (Malhotra and Ackfeldt, 2016) and thus neglects other internal organisational communication practices, such as horizontal cross-functional communication. Therefore, not only has internal organisational communication received significantly less focus relative to other internal communication practices, the horizontal cross-functional form this might take within 
organisations has been starkly ignored. This knowledge gap leads to the first research question (RQ1): What form does cross-functional communication take within organisations?

Central to an examination of organisational internal communication practices is organisations' work climate, defined as 'the shared perceptions of procedures, policies, and practices, both formal and informal, of the organization' (Simha \& Cullen, 2012, p. 20). Work climates have been observed to influence organisational actors' behaviour within organisations, with numerous climates having been examined across disciplinary fields (e.g. innovation climates, creativity climates, justice climates, diversity climates, ethical climates, motivational climates, achievement climates, among others) (Gibson \& Gibbs, 2006; Simha \& Cullen, 2012). A communication climate is a recognised work climate (Simha \& Cullen, 2012) pertinent to this study of internal organisational communication practices. Communication climate is defined as 'the atmosphere that allows information to flow freely within an organization' (Zsidisin, Hartley, Bernardes \& Saunders, 2015, p. 550). However, a communication climate is more nuanced than the definition implies, with potential for significant variation in how information flows across different organisations (e.g. Forward et al., 2011). While Gibb' (1961) distinction between supportive and defensive communication climates endures, a more fine-grained investigation of the interplay between internal organisational communication practices and features of communication work climates is still lacking, in part because of the scholarly neglect of internal organisational communication (cf. Nurmi \& Koroma, 2020). Consequently, the need for a reconceptualisation of the supportive-defensive construct as called for by Forward et al. (2011) remains. This knowledge requirement leads to the second research question (RQ2): how do features of the communication climate influence cross-functional communication? 
To address the two inter-related research questions, the study focuses on marketing and media functions among 33 professional football organisations operating in the English Premier League (EPL). The case for focusing on the professional football industry is presented by Brady, Bolchover, and Sturgess (2008, p. 59) who claim that 'Football not only replicates the problems faced by business, but also intensifies them and accelerates the decision-making process by compressing the time-scale and heightening the focus owing to the relentless nature of media attention'. The domain has, thus, served as a useful setting for mainstream business and management investigations (e.g. Desai, Lockett \& Paton, 2018; Gerrard \& Lockett, 2018; Hughes, Hughes, Mellahi \& Guermat, 2010). Moreover, the EPL represents a definable and observable ecosystem, which enables exploration of the presence of, and interplay between, internal cross-functional communication and features of communication climates in depth.

In addressing the two research questions, two contributions are made to the marketing and communications literature. First, by exploring the interactions between internal communication practices and features of the communication climate across two organisational functions-media and marketing-the study addresses the need for greater knowledge of the forms that internal organisational communication can take in practice, as emphasised by Malhotra and Ackfeldt (2016). It is particularly necessary to go beyond both the project and peer-to-peer levels that have been the focus of the extant marketing and communications literature, as well as exploring alternative organisational communication forms to the traditional top-down corporate communication that has been examined previously (e.g. Welch \& Jackson, 2007). In doing so, this study responds to the need for greater focus on employees' communicative role, which remains an 'understudied aspect of organisations' strategic communication' (Andersson, 2019, p. $61)$. 
Second, the study moves the internal communications narrative beyond the depiction of, and reliance on, Gibb's (1961) supportive-defensive communication climate construct and the inferred linear associations with different internal small-group communication practices. Specifically, the study provides a novel investigation of the influence of communication climates on employees' organisational behaviour and their strategic communicative capacities, which remains understudied (Andersson, 2019). In uncovering three unique and conceptually distinct types of internal organisational communication, the study generates new insights into how internal organisational communication practices are shaped and influenced by communication climates. Collectively, the study serves as a basis for the reconceptualisation of existing marketing communications theory and models.

\section{Theoretical background}

\section{Internal communication}

Cross-disciplinary literature exists on internal communication practices, with scholars using various perspectives to explore and discuss the phenomenon from internal relations (Grunig et al., 1992), employee communication (Smidts, Pruyn \& van Riel, 2001), internal communication (Cornelissen, 2017), employee relations (Quirke, 2012), internal public relations (Wright, 1995), and internal marketing (Ahmed \& Rafiq, 2003). In the marketing field specifically, studies typically focus on managing customer relationships rather than on the dynamics of supporting employees (Malhotra \& Ackfeldt, 2016). Hence, most extant studies shed light on how employees identify with the brand of the organisation they are employed by and the consequences for marketing performance (e.g. Andersson, 2019). For instance, Morhart et al. (2009) and Punjaisri et al. (2008) infer internal communication is an implicit feature that can 
affect employee overall performance within the organisation. Boukis, Gounaris, and Lings (2017), Burmann et al. (2009), and King (2010) among others, have further observed that internal marketing can positively influence the way in which brand identity is perceived outwardly by customers; a relationship empirically evidenced among hotel reception employees (Buil, Martínez, \& Matute, 2016), sales employees, (Du Preez, Bendixen, \& Abratt, 2017), and sport coaches (Gorchels \& Aurand, 2006). However, internal communication is relegated to the background of such studies where its importance and role are often inferred, but not explicitly addressed. Consequently, Malhotra and Ackfeldt (2016, p. 4133) contend 'empirical research examining the significance and role of internal communication is warranted to help organizations understand how internal communication could foster an effective internal service climate'. The study addresses this neglect in the marketing field by positioning internal organisational communication practices in the foreground.

When internal communication has been directly examined, most extant studies treat internal communication as a project- or team-level phenomenon. In contrast, this study adopts Frank and Brownell's (1989, p. 5) definition of internal communication as all 'communication transactions between individuals within an organisation'. This definition conceptualises internal communication as comprising all communicative exchanges that occur among co-workers, managers, team members, committees, and task forces within an organisation, as well as exchanges aimed toward accomplishing company goals and objectives (Cornelissen, 2017). Internal communicative exchanges have been suggested to comprise of formal, vertical communication (e.g. managers providing employees with task directions, workplace policies and performance objectives and feedback); upward communication (e.g. employees informing their managers about workplace and task updates, concerns, problems, suggestions or complaints); 
horizontal communication (e.g. co-worker coordination and information sharing on a task); and, informal communication (e.g. co-workers' discussion on work and non-work related topics) (Harris, 1993). According to Welch and Jackson (2007, p. 184), these different forms of internal communication can occur at distinct dimensional levels comprising 'internal line manager communication, internal team peer communication, internal project peer communication and internal corporate communication'. These dimensional levels are presented in Welch and Jackson's (2007) internal communication matrix, which outlines the various levels, directions, participants, and content of each internal communication dimension. Beyond peer-to-peer communication with team colleagues and/or project group colleagues, internal corporate communication is the only form of internal communication to exist at the organisational level and prescribes clear, consistent and continuous communication from top management to all employees (Malhotra \& Ackfeldt, 2016; Ridder, 2004; Ruck \& Welch, 2012). However, despite recognising the organisational level, there is a bias towards vertical, top-down communication consistent with the approach of treating employees as passive recipients of communication (Andersson, 2019). Thus, the matrix neglects organisation-wide, cross-functional communication where employees act as key strategic communicators (e.g. Andersson, 2019).

The need to transcend interdepartmental barriers through structural design and crossfunctional collaboration is receiving increasing scholarly support (Luxton et al., 2017) with benefits noted for building employee engagement throughout an organisation (Ridder, 2004), knowledge sharing, efficiency, security and motivation (Kalla, 2005), as well as motivating and inspiring employees to align to 'organisational values and the brand vision' (Matanda \& Ndubisi, 2013, p. 1034). On the other hand, communication silos between functions have been identified as a challenge and barrier to the progress of outward strategic communication and brand 
management (Cornelissen, 2017). There is consensus that the two approaches form opposite ends of a single internal communication continuum, with cross-functionality at one end deemed favourable for marketing effectiveness, and functional silos at the other end deemed ineffective. Yet, with the extant marketing literature largely neglecting organisational forms of crossfunctional communication, there is a pressing need to recognise the communicative importance of employees as strategic communicators who are central to all forms of organising, managing and strategizing in the organisation (Andersson, 2019). Exploring the forms that cross-functional communication takes within organisations (RQ1) is therefore a critical step forward in addressing this need.

\section{Communication climate}

Though recognised as one of many types of work climate by Simha and Cullen (2012), communication climate continues to receive disparate scholarly attention relative to other work climates. Broadly, communication climate can be understood as 'a subjectively experienced quality of the internal environment of an organization...identifiable through reports of members' perceptions of messages and message related events occurring in the organization' (Dennis, 1974, p. 29, as cited in Guzley, 1992).

Gibb's (1961) seminal distinction between two contrasting types of communication climate, supportive and defensive, remains an enduring reference point for internal communication studies despite the limited empirical evidence supporting the supportivedefensive construct (Forward et al., 2011). In a supportive workplace, communication is clear and accurate, information is freely shared, employee opinions are accepted, individuals are encouraged to achieve their goals, and most importantly, accusation and blame are minimized 
(Forward et al., 2011). Furthermore, according to van den Hooff and de Ridder (2004, p. 120), 'a supportive communication climate is characterized by open exchange of information, accessibility of co-workers, confirming and cooperative interactions and an overall culture of knowledge sharing'. In this climate, employees engage in all directional forms of formal and informal communication openly (Zsidisin et al., 2015), which benefits knowledge sharing and knowledge donating (van den Hooff \& de Ridder, 2004).

In contrast, in a defensive communication climate, employees' contributions are neither welcomed nor valued, while employees themselves feel stifled, threatened and confused, and though the exchange 'may appear normal outwardly...inwardly the person is investing considerable mental energy in defending him or herself' (Forward et al., 2011, p. 2). Subsequently, employees feel disengaged with their role, the department and/or organisation, with potential to generate friction between employees, teams or departments (Bernsen, Segers \& Tillema, 2009). Within a defensive communication climate both formal and informal communication is treated sceptically, with employees less inclined to use written or mediated channels because they are fearful that this could be held against them (e.g. disciplinaries, in performance appraisals, etc.). As a result, a less frequent and rather unstructured communication is favoured, which can impede productivity (Smidts et al., 2001).

Clearly such communication climates and their associated workplace dynamics will impact internal communication practices. As was central to Gibb's (1961) theorisation, this same premise has informed the burgeoning body of subsequent research on small groups, (virtual) teams and interpersonal communication related to (psychologically safe) communication climates (e.g. Forward et al., 2011; Gibson \& Gibbs, 2006; Newman, Donohueb \& Evab, 2017). The lack of investigations of internal communication at the organisational level, however, 
highlights the concern flagged by Andersson (2019) that scholars have largely ignored strategic internal communication practices. Nurmi and Koroma (2020) offer one of the few exceptions to this in their examination of the concept of language-supportive communication climate among multinational companies, which extends and abstracts previous research examining psychological-safe (supportive) communication climates among teams (e.g. Gibson \& Gibbs, 2006), to the organisational-level.

Since internal communication has been associated with organisational success (e.g. Conduit, Matanda, \& Mavondo, 2014; Matanda \& Ndubisi, 2013), an extension of knowledge about the role played by communication climates for internal organisational communication practices is now a necessity. For instance, it is not clear whether the supportive and defensive communication climates represent grand climates present across all organisations, or if other types of communication climates exist; and if other communication climates do exist, whether the specific workplace dynamics of these alternate communication climates influence internal organisational communication practices. Investigating the features of an organisation's communication climate and how these features might influence cross-functional internal communication practices (RQ2), thus, is essential to progress communication climate theory.

\section{Methods}

Research Setting

Football organisations are said to exhibit advanced management practices and can 'act as a precursor and predictor of future organizational priorities in business', it is therefore an ideal setting for examining modern-day talent and knowledge dependant businesses (Brady et al., 2008, p. 60). According to Hughes et al. (2010), the professional football domain is advantageous as a 
setting for empirical marketing and management research given that industry forces are consistent for all organisations, organisational structures are relatively straightforward; organisations cannot acquire each other, and organisations are limited in the ability to acquire new resources at short notice; collectively increasing the internal validity of findings. At the end of the study time period (2016-17), EPL football organisations recorded an aggregate operating profit of over £1 billion (Deloitte, 2019).

\section{Data generation}

Given the fast paced and highly pressured environment facing football organisations (Brady et al., 2008; Manoli, 2016; 2017; Manoli \& Hodgkinson, 2017), internal communication becomes an increasingly 'complex, interpretative process' (Dolphin, 2005, p. 173). Building on the insights of Starbuck (2010, p. 1397) that 'Researchers can learn things that are more useful by investigating carefully selected instances and noticing peculiar or distinctive properties of these instances', multiple organisations were selected to uncover relationships between crossfunctional internal communication, communication climate, and outward communication. The 33 organisations selected operated in any of the seven EPL seasons between 2010 and 2017.

Qualitative interviewing was deemed a suitable method to understand the way individuals from across organisational functions construe, conceptualise, and understand internal communication and the wider communication climate. The methodology employed is justified on the premise that communication climate is 'subjectively experienced' and can be understood 'through reports of members' perceptions' (Dennis, 1974, p. 29, as cited in Guzley, 1992). Qualitative interviewing using 'active listening' was adopted in the hope of revealing more realistic insights that exist behind façades by using questions that 'encourage speakers to 
continue talking: "Tell me more". "What did you do then?" "How did that make you feel?" "Uhhuh". "That is interesting"... with the result that many speakers talk more freely than they normally would.' (Starbuck, 2010, p. 1398). The interviews targeted the most senior employee in charge of marketing, media ${ }^{1}$ or marketing and media from each organisation (see Appendix A for more information on the interviewees and organisations). The key informant approach is consistent with the centrality of personnel to the origins of internal communication (Dolphin, 2005). The approach is further justified on the premise that informants can generalise about 'patterns of behaviour', especially given the relatively small number of marketing and media staff employed among the selected organisations, and the most senior organisational member is 'chosen because they are supposedly knowledgeable about the issues being researched and able and willing to communicate about them' (Kumar et al., 1993, p. 1634).

All interviews were conducted in person, with the average length of interview being 65 minutes. Mindful of social desirability effects, efforts were made to ask similar questions in different ways, probe informants' explanations and justifications in-depth, and triangulate apparent contradictions and inconsistencies. A sample list of interview questions can be found in Appendix B. After the interviews were conducted, they were then transcribed, producing on average 8 pages of single-spaced text per interview.

\section{Data analysis}

\footnotetext{
${ }^{1}$ The term media is used here to describe both the media function and the communications function of an organisation, following the common practice of using the terms interchangeably, in order to avoid confusion between the act of communicating and the communications function of an organisation (Manoli, 2017).
} 
All interview transcripts were sent to the interviewees so any inaccuracies or misinterpretations could be highlighted and the accuracy of the interviews verified. After member-checking, the data were analysed manually through thematic analysis following Braun and Clarke's (2006, p.16) six phases of thematic analysis, which unlike other methods of data analysis focuses on identifying patterns of meaning in data. The first phase of data analysis-familiarisation with the data-commenced immediately during the transcription of the interviews and continued with the repeated reading of the transcripts. Phase two-generating the initial codes-encompassed the researchers identifying initial codes in the data, in order to form first-order codes. Phase three-searching for themes-entailed clustering and integrating first-order codes for wider themes on internal communications practices and communications climates to emerge. Phase four-reviewing themes-involved a meticulous checking of the themes in relation to the coded quotes and the full dataset. A 'thematic map' with all themes, sub-themes and codes identified was developed in this phase, which allowed for each theme to be refined, clarified and labelled appropriately. In phase five-defining and naming themes- the researchers focused on delimiting theory by aggregating theoretical dimensions. Once theoretical categories had been generated, underpinning dimensions underlying these categories were identified to understand how different categories fitted together within a coherent internal communication 'type'. Finally, phase six-producing the report-entailed further examination of the analysed data to determine fit with the analysis and underpinning theories. To ensure robustness, the codes and themes identified were verified through intra (coding in two different moments in time) and inter (coding by different coders) coding agreement. The intra and inter coding reliability was calculated by scoring the percentage of similarity between the codes produced during each process, with both intra and inter coder reliability scoring higher than 90\% (Boyatzis, 1998). 


\section{Findings}

In response to the study's two research questions, three patterns of cross-functional communication and associated communication climates emerged from the data, as depicted in Figures 1-3 and comprising: 'Type 1 Collaborative symmetrical communication (Cohesive climate)', 'Type 2 Unstructured informal communication (Friendly climate)', and 'Type 3 Crossfunctional silos (Divisive climate)'. The conceptual and empirical distinctiveness of each type is examined and discussed below in turn, alongside typical quotes from the study's interviewees which help to illustrate the types that emerged.

Type 1: Collaborative symmetrical communication (Cohesive climate)

Six of the organisations drew the picture of symmetrical communication between marketing and media employees. Here, formal downward, upward and horizontal, as well as informal communication, takes place between the two functional teams:

We are in contact 24/7. We talk all the time, both formally and informally. We have very good interpersonal relationships with them which helps, but our roles and the process we follow put us in constant contact with them (AA).

As the quote shows, the two functional teams within these football organisations are in frequent communication both on a formal and on an informal basis, with interviewees perceiving these communication approaches as part of their roles. Similarly to how studies on supportive communication climate between small groups suggest (Forward et al., 2011; Kirby et al., 2003; 
Martin, 2010; Smidts et al., 2001), in these organisations, communication and collaboration between the two functions are not only considered desirable, but also necessary for marketing and media tasks to be completed efficiently. Cross-functional communication is encouraged through carefully designed processes, including numerous weekly meetings that reinforce teamwork and openness between employees of different functions. In these meetings, all members of the marketing and media functions, including those in the most junior of roles, are encouraged to collaborate and share views:

We tend to meet quite regularly and in general, that is the ethos here: you talk to each other, you co-ordinate, you collaborate. Not only within each team but in a way throughout the club, from the most junior to the most senior employee, we all collaborate here (Q).

The layout of the offices and the adoption of an 'open office' policy, in which members of the two functions share a common space along with members of other departments (e.g. commercial, human resources and logistics), was presented as a factor that enhances communication. This 'open office' policy is a key factor in enhancing less structured, informal communication. In this communication climate, less structured cross-functional communication is encouraged, but not at the expense of formal structures and processes within the club. Thus, formality and informality appear to coexist in harmony in the internal communication practices adopted. Greater agility is then created for seizing opportunities, as the quote below illustrates:

We have these seize-the-moment opportunities and when they come, we cannot wait for a meeting. We email someone, or event run to their desk, grab them and discuss details on how to 
get a win. After we finish each task, we'll of course keep a note of it and report it in our marcoms meeting, but we tend to mix things up since some opportunities are too good to miss (V).

The mixed approach described allows this club to respond quickly and is, therefore, fostered within all football organisations that fall under this theme. Regular meetings to ensure a formal process of interaction, while designing office layout to encourage informal interactions (i.e., geographical proximity between the two teams' desks) were presented as the main reasons behind the frequent formal and informal horizontal communication. Friendships did not feature here but interviewees made clear that communicating openly and frequently is a prerequisite for each employee's role:

Talking, communicating openly and frequently is the only way to get the job done and right. We are all here to do the best we can, to represent the club, its brand, its meaning, what it stands for. If we don't talk to each other, how are we going to make sure that what is communicated externally is on the same page, or 'on brand' as we say? (B).

For outward marketing communication, the quote above illustrates that cross-functional communication is believed to be an indispensable tool for achieving the one-voice or the same look and feel in their branding. Frequent, two-way horizontal cross-functional communication is, thus, a key factor for achieving a consistent and coherent brand message in outward communication.

As the above analysis illustrates, the image drawn by these six organisations represents the first type of internal communication identified, which is characterised by cooperative interactions between teams, which foster an open exchange of information throughout each 
organisation, while allowing accessibility and support to co-workers in order to achieve an aligned external communication. These key characteristics identified represent the skeleton of type 1: collaborative symmetrical communication as they are illustrated in Figure 1. Type 1 appears to be favoured by a Cohesive communication work climate within the organisation, which further encourages cooperation among employees. This type of internal communication type mirrors desirable cross-functional collaboration (Luxton et al., 2017), which research suggests could prove beneficial to an organisation in terms of employee efficiency and motivation (Kalla, 2005; Matanda \& Ndubisi, 2013). As the interviewees from these six organisations suggested, an additional managerial implication of this type is the increased efficiency of outwards communications, which in turn enables effective alignment of marketing and media outcomes outside the organisation.

\section{INSERT FIGURE 1 HERE}

\section{Type 2: Unstructured informal communication (Friendly climate)}

For nine other football organisations, employees interact with each other daily, but the communication between them appears to be predominantly unstructured and conducted on an informal basis. In fact, informal ways of communication supersede any formal procedures, as the following quote shows:

We talk all the time, since we practically sit together. Their desks are next to ours, so we don't even need to pick up the phone. We will put things on an email only if we want something to be formal; Otherwise, I can just turn my chair and ask them something (J). 
Informal communication is justified in these organisations due its easiness and promptness, leading to an unstructured and more fluid approach overall to outward marketing. Downward and upward communication does not follow a formal approach either, with the interviewees showing an overall reluctance to use popular methods of internal communication such as emails. In fact, emails were deemed 'too formal' and 'too slow', which made the interviewees suggest that a 'more direct' approach, like face-to-face interaction, was preferred. Less emphasis, then, is placed on formal processes in these football organisations, who instead favour a direct, unstructured and 'seize-the-moment' approach: if there's something important that they should know I just tell them (L).

All nine interviewees underlined the importance of 'getting the brand right' suggesting that this informal direct approach assists in the careful design of their outward communication messages, as the following quote illustrates:

Say you want to get a press release out or a tweet about a new sponsor, you learn to go over, grab one of the media guys and ask them: is this right? Does it read like it's supposed to? Does it say it's us? If it's not right, then we sit down together and fix it. We know that getting the brand right is important and this directness helps $(\mathrm{F})$.

The interviewees suggested that direct communication is encouraged within these organisations since 'it gets the work done quickly'. While this informality is believed to assist in increasing employee engagement both among individuals and between the employee and the organisation (Grosser et al., 2010), limiting all internal communication to this informal approach could be deemed risky. For example, when a task or a project is designed, planned and managed, limiting 
all internal project peer communication to an informal face-to-face approach could reduce the potential to identify and track any errors in the process and, therefore, potentially obstruct progress. Favouring face-to-face interactions between individuals could also hinder any efforts for downward and upward formal communication between hierarchical levels within the organisation (e.g. CEO, COO). Nevertheless, informal cross-functional communication was presented as symmetrical by the interviewees, who appreciate brand message consistency in their outward communication and try to achieve it through their direct internal communication approach. According to the interviewees, their unstructured internal communication approach assists them in accomplishing this consistency quickly and easily. This perceived 'easiness', could be attributable to the extreme degree of informality serving as a bonding agent between peers and among individuals and the organisation (Grosser et al., 2010).

The workplace environment described by the interviewees does not align with either a supportive or a defensive climate as they have been captured by academia so far, indicating the existence of a different communication work climate. This friendly climate bears similarities with the supportive climate discussed by Forward et al. (2011), Kirby et al. (2003) and Martin (2010), and the cohesive communication work climate described above, since cross-functional peer communication is being fostered. Yet the complete lack of formal means of internal communication distinguishes this as a distinct communication work climate. There is no harmony between the extreme informality reported and formality in communication practices, which makes it conceptually very distinct. A potential pitfall for outward communication here, however, is that the effectiveness and long-term stability of the climate might be disturbed if this informal communication is interrupted abruptly (for example by the replacement of some 
individuals). As a result, the longevity of this friendly communication climate may be threatened as there are no formal communication structures in place to ensure continuity.

This second type of internal communication identified was defined by informal direct interactions within an organisation, which allowed for peer-to-peer communication, support and responsiveness across business functions, but completely unstructured. These key characteristics of type 2: unstructured informal communication, which are illustrated in Figure 2, comprise a 'friendly' communication climate, which fosters the informal interactions between employees, while lacking organised processes and procedures around them. Though an element of informality in internal communications is believed to be beneficial in terms of employee engagement (Grosser, Lopez-Kidwell, \& Labianca, 2010), the existence of an internal communication type based solely on unstructured informality as suggested by the findings discussed above could prove harmful for the efficiency of an organisation; especially in terms of the continuity of an unsystematic approach to an organisation's external communication.

\section{INSERT FIGURE 2 HERE}

\section{Type 3: Cross-functional silos (Divisive climate)}

18 football organisations appear to be unable (or unwilling) to establish open and symmetrical communication between the marketing and media functions, despite frequent daily interactions. In fact, the two functions in these organisations do not seem to communicate or collaborate at all unless a project requires them to do so. When the teams need to work together, the communication between them is unbalanced as illustrated by the following quote: 
We are fairly close in the sense that there is a lot of interchanging workloads. They ask us to do something very often...It's a one-way-street, asking, requesting stuff from us and we don't really have any demands from them... We don't really operate like we're in the same club (AD).

This project peer-peer communication is, therefore, not presented as a symmetrical, two-way approach like Grunig et al. (1992) and Welch and Jackson (2007) suggest, but more akin to a one-way, asymmetrical communication; which may be unfavourable for one of the functions. 11 of the interviewees highlighted that cross-functional communication is not reciprocal resulting in '...they say, we do' attitudes (K).

Communication between marketing and media employees exists through projects only and takes a formal task-focus form, while informal communication is absent. At the same time, infrequent formal cross-functional meetings involve only the directors of each function and as a result no formal process is in place to encourage other team members to communicate with their peers. Consequently, the overall cross-functional communication within the club is hindered. This is compounded by physical separation of the marketing and media functions, who are often located in separate offices or even in separate buildings (marketing function based in the stadium and media function based in the training ground), further hindering any informal communication. Nevertheless, even when the two functions share the same office and are also under the same department, such as in football organisations A, S, AC and AE, internal silos exist and hinder the collaboration between the two teams. These silos and the subsequent lack of cross-functional communication obstructs the individuals from collaborating and co-ordinating the outward communication messages of the club as a whole; as the following quote indicates: 
We have very distinct identities here. The media is all about being friendly and open to our fans and the marketing is all about numbers to our sponsors, so there's no real reason for me to tell them what to do or them to tell me what to do (A).

Overlapping workload or the need to work on projects together are the only drivers of collaboration, with individuals feeling forced or at a minimum obligated to communicate between functions. A description that resembles Smidts et al. (2001) and Bernsen et al. (2009) descriptions of the form of communication that occurs between peers in a defensive communication climate. In the divisive communication climate identified, each function operates as a separate and isolated 'functional silo', hindering any open dialogue and often creating tension between employees. The potential damaging effects of this inability to communicate and collaborate between functions is illustrated by a media manager:

The marketing guys had access to our twitter and they would often post stuff without asking or discussing it with us. The tone was different, the voice was different and the actual message was irrelevant to the fans. It didn't match the twitter personality we had built. The problem was not only upsetting the fans, but damaging the brand and the voice we had carefully built (I).

Silos, then, do not only obstruct internal communication, but can also harm a company's outward communication significantly by damaging the consistency of its voice, whether that be on online or offline platforms; as numerous studies have argued (e.g. Keller, 2016; Luxton et al., 2017).

The third type of internal communication identified was characterised by functional silos within an organisation, where communication between functions was described as transactional, 
task-oriented and self-justifying. These characteristics represent the backbone of type 3: crossfunctional silos and are illustrated in Figure 3. Unlike the above presented types and the ideal internal supportive communication climate discussed in extant communications research (Grunig et al.,1992; Welch \& Jackson, 2007), this type of internal communication was embedded within a divisive climate, in which internal communication is guided by division and disconnection between teams (e.g. Smidts et al., 2001; Bernsen et al., 2009). The significant managerial drawback of this internal communication type, as it emerged through the findings, is misaligned external communication, which could prove harmful for external brand consistency and coherency.

INSERT FIGURE 3 HERE

Table 1 presents a comparison of the three types of internal organisational communication and the associated characteristics of each type. This classification of general types contributes a new internal organisational communications typology to the marketing and communications literature.

INSERT TABLE 1 HERE

\section{Discussion}

Contributions to theory 
Andersson (2019, p. 71) contends that 'researchers and practitioners must start taking employees' communication seriously' and the study findings reveal why this is indeed necessary. Specifically, the article presents a far more complex picture of internal organisational communication relative to existing internal communication classifications and models. In turn, the study offers a critical advancement of knowledge in the form of two core contributions to the marketing and communications field.

First, moving beyond the dominant focus on vertical and task-focused communication at the team or project levels, the study reveals three types of cross-functional communication and associated communication work climates: Type 1: Collaborative symmetrical communication (Cohesive climate), Type 2: Unstructured informal communication (Friendly climate), and Type 3: Cross-functional silos (Divisive climate). Table 1 presents the three unique types and associated characteristics, providing a new typology of internal organisational communication, which has been a missing critical element of existing internal communication theory and models (e.g. Ruck \& Welch, 2012; Welch \& Jackson, 2007). By revealing the different types of crossfunctional communication and associated communication climate features, the study furthers understanding of the spectrum of internal organisational communication practices and their key characteristics, which in turn helps to unpack the 'black-box' of internal organisational communication.

Moreover, while internal communication is an important element of effective marketing practices (e.g. Piha and Avlonitis, 2018), many organisations appear to be closely aligned to the behaviours and characteristics of type 3, which is deemed the least effective approach to internal organisational communication. The prevalence of this type may be because of a misplaced belief in task or project-oriented communication behaviour, which is at the core of cross-functional 
communication within this type. as Forward et al. (2011) highlight, Gibb' (1961) supportive versus defensive construct was developed in the context of small, task-oriented groups and similarly most extant communication studies are also positioned at this level (e.g. Gibson \& Gibbs, 2006; Welch and Jackson, 2007). Consequently, many of the organisations studied appear to reflect this bias toward task- and project-oriented communication practices and corresponding communication climate characteristics of transactional, task-oriented and self-justifying communication. Type 3 is reflective of the traditional view of employees 'as passive recipients of communication activities rather than strategic communicators whose communication activities have consequences for the organization' (Andersson, 2019, pp. 60-1). Cross-functional communication (both formal and informal) at the organisational-level is subsequently much less likely to occur under type 3 , as the findings of this study illustrate. By providing a disaggregation of the characteristics associated with each approach to internal organisational communication, the findings distinguish between the ineffective features of type 3 where employees play a passive role, and the effective organisational communication features of types 1 and 2 where employees are active, strategic communicators, which is desirable for the achievement of organizational goals (e.g. Andersson, 2019). The contribution made here, then, is a direct extension of extant organisational communication theory and models. Through this new typology, it is suggested that existing internal communication models such as Welch and Jackson's (2007) internal communication matrix, should be reconceptualised to encapsulate the various forms of cross-functional organisational internal communication that have been revealed.

Second, linked to the first contribution the study responds to the need for a reconceptualization of communication climate and a need to move beyond the reliance on the Gibb' (1961) supportive-defensive construct. The findings of this study, as illustrated in Table 1, 
show that two of the three communication types (type 1 and type 3 ) uncovered share some characteristics of the supportive (type 1) and defensive (type 3) communication climates, as previously documented by Forward et al. (2011), Gibb (1961), Gibson and Gibbs (2006), Kirby et al. (2003), Martin (2010), Nurmi and Koroma (2020), and Smidts et al. (2001). However, despite sharing some similarities, type 1 is conceptually distinct from Gibb' supportive climate and similarly, type 3 is conceptually distinct from Gibb' defensive climate. Specifically, type 1 offers insights into how a cohesive climate operates and its harmonised two-way internal communication practices, in which cross-functional communication is encouraged and supported by formal processes and protocols. Type 1 also indicates that cohesive climates promote collaborative symmetrical internal communication, which appears to result in coherency and consistency in outward communication. On the other hand, type 3 and its divisive climate is linked with cross-functional silos within an organisation, leading to an absence of informal communication between functions in favour of task-focused, asymmetrical internal communication. The communication practices and climate features of type 3 appear, in turn, to result in un-coordinated outward communication, which is potentially damaging for outward marketing success.

A further distinct type of internal organisational communication emerged through this study and was labelled type 2: unstructured informal communication (friendly climate). This type replaces all traditional forms of formal upward, downward, and/or horizontal communication with unstructured informal communication. Though the conceptual features of type 2 may appear at first glance to reflect characteristics of the cohesive climate and communication characteristics of type 1 , it is in fact conceptually distinct given the absence of formal, cross-functional communication. This would suggest that type 2 internal organisational 
communication develops organically and is sustained through an unconscious value system that reinforces expected communication practices. The emergence of type 2 also suggests that the existence of formal processes is not a necessary defining factor for coherent and consistent outward communication, in contrast to what is recommended in the extant marketing and communications literature (Conduit et al., 2014; Matanda and Ndubisi, 2013; Piha and Avlonitis, 2018; Ridder, 2004). Its emergence therefore raises important questions about whether assumed 'best practices' in internal communication are still relevant or if these traditional prescriptions should be superseded.

As Teece (2014, p. 331) outlines, 'good and even "best" practices diffuse rather quickly', and thus become insufficient for organisational success. Nevertheless, though greater agility may be enabled, there is potential for communication chaos to ensue given the absence of 'control' features, which could in turn damage outward marketing success as defined by features of coherency and consistency. Recent research, however, points to how the climate characteristics under type 2 may mitigate this potentially dangerous scenario. Supported by a friendly climate that values openness, under this type there is likely to be a stronger employee predisposition towards taking communication responsibility, i.e. formal and informal accountability for internal and external communication (e.g. Andersson, 2019). As a result, it could be argued that a shift from traditional 'best practices' that are highly prescriptive, towards empowering employees to take new strategic communication responsibility may be a novel route to effective internal organisational communication strategies of the future. The study therefore provides a stepchange in established thinking concerning internal organisational communication by offering a much more nuanced and complex representation of internal organisational communication types 
than previously understood or captured in the extant internal marketing and communications literature.

\section{Implications for Practice}

The professional football domain provides new techniques for managers and predicts new organisational priorities, particularly for those organisations reliant on knowledge workers and the relationship between people management, performance, and results (Brady et al., 2008). Given this setting produced the findings which underpin the creation of a new organisational communications typology, we expect the insights generated to hold for marketeers across various organisations and sectors.

Type 1: Collaborative symmetrical communication (cohesive climate) is closely aligned to the observations of Conduit et al. (2014, p. 1340) that in 'organisations with an atmosphere of collaboration, there is open communication both formally and informally allowing sharing of information'. Nevertheless, the findings suggest that type 1 is adopted by only a small number of organisations. Rather, it is type 3 that appears to prevail among the organisations examined, despite its propensity to obstruct internal communication efforts and damage outward marketing success. These observed functional silos obstruct cross-functional communication and can prove harmful to the consistency and coherency of outward communication. Though Homburg and Jensen (2007) argue that 'function wars', which appear prevalent under the divisive communication climate of type 3, are gradually overcome, the prevalence of this type does suggest that the current dominant practices of internal organisational communication among 
professional football organisations are sub-optimal. In turn, since professional football organisations are said to set the standard for innovative management approaches across the business arena (e.g. Brady et al., 2008), we flag to managers the critical need for an evaluation of the internal organisational communication practices of their own organisations, as these are likely to reflect the same bias towards type 3 .

For organisations who might self-classify as type 3 , the internal communication practices, and the associated features of type 1 and type 2 approaches to internal organisational communication offer a way forward. Table 1 outlines the characteristics of each internal organisational communication type and can be used as a clear guide to evaluate and classify organisations and, importantly, provides a clear vision of what is (un)desirable. For example, clearly there will be very few firms who would be content to enact and support type 3 internal organisational communication. As such, Table 1 can not only help organisations identify the internal organisational communication type their current practices correspond to, but it can also act as a roadmap for practitioners who would like to progress their approach towards type 1, for example, and thus a more collaborative symmetrical communication type. In other words, Table 1 can act as a tool to allow for self-reflection on the current approach adopted within each organisation, while simultaneously identifying the steps that need to be taken in order for a different communication type to be achieved.

As a result, organisations that might identify their current focus on task-driven asymmetrical communication and internal functional silos (type 3), could be assisted to potentially progress from type 3 to type 1 , which maintains a balance between formal and informal internal organisational communication, and can achieve a more coherent and consistent brand message. In order to do so, organisations should establish protocols to foster cross- 
functional communication beyond specific tasks by potentially introducing more regular and informal cross-functional interactions, encouraging employees to adopt company-wide cooperative interactions, open-exchange of information, mutual support, and increased accessibility to one another with the shared value of aligned communication. For creative and fast-paced industries, a transition to the type 2 internal organisational communication may be more appropriate which can be fostered through establishing a supportive environment and the same shared value of aligned communication as in type 1, but with an internal organisational communication architecture that promotes a continuous, informal and direct interaction and peerto-peer communication among employees, which is highly responsive to knowledge and information.

The insights generated by the findings of this study move the guidance for managers away from vertical, top-down internal organisational communication practices only, which have dominated existing models, towards cross-functional communication. The new internal organisational communication typology also progresses guidance to managers away from a reliance on the over simplified supportive-defensive communication climate construct, towards a clear and detailed picture of the range of internal organisational communication forms. Lastly, the new typology offers a clear demonstration of what the undesirable type 3 divisive climate comprises of and, by presenting alternative and more desirable internal organisational communication types, the new typology offers actionable insights for internal marketing communication transformation.

\section{Limitations and further research}


There are several limitations to acknowledge: first, the findings are generalised from the single perspective of the most senior person in the marketing and/or media function(s). Having multiple interviewees per organisation would have allowed for a more detailed interpretation of the internal communication practices and communication climates among the organisations studied. Nevertheless, due to the limited number of employees and scheduling challenges arising from the high-profile nature of the football organisations, the single-informant approach was deemed a 'necessary evil' to address the research questions. Second, the study is based on a cross-sectional qualitative research design and by consequence, the evolving communication climate and the internal communication dynamics over time cannot be captured which is acknowledged as a limitation. Third, reflections on how cross-functional communication might influence outward communication are presented but it is acknowledged that 'success' of outward marketing was not directly measured and, thus, the consequences of the three types for outward marketing requires further investigation. Finally, the study draws on qualitative data from professional football organisations only. Nevertheless, as noted by Brady et al. (2008), the professional football domain both replicates and intensifies the problems faced by business managers and leaders, thus, it is argued that the findings are generalisable.

For future research, the internal organisational communications typology presented in Table 1 provides a firm foundation for the next generation of internal organisational communication research. A multi-case, longitudinal qualitative investigation would be an appropriate next step to (a) track the evolution of internal communication and communication climate types over time, (b) examine the transformation process from type 3 to another type and the required capabilities to do so, and (c) establish the consequences of the three types for outward marketing success across a broader set of organisations. 


\section{References}

Ahmed, P.K. and Rafiq, M. (2003), “Internal marketing issues and challenges”. European Journal of Marketing, Vol. 37 No. 9, pp. 1177-1186.

Andersson, R. (2019), “Employee communication responsibility: its antecedents and implications for strategic communication management”. International Journal of Strategic Communication, Vol. 13 No. 1, pp.60-75.

Bernsen, P., Segers, M. and Tillema, H.H. (2009), "Learning under pressure: Learning strategies, communication climate, and leadership style in the hospitality industry". International Journal of Human Resources Development and Management, Vol. 9 No. 4, pp. 358-373.

Beverland, M. and Luxton, S. (2005), “The projection of authenticity: Managing integrated marketing communications through strategic decoupling”. Journal of Advertising, Vol. 34 No. 4, pp. 103-116.

Brady, C., Bolchover, D. and Sturgess, B. (2008), "Managing in the talent economy: The football model for business". California Management Review, Vol. 50 No. 4, pp. 54-73.

Boukis, A., Gounaris, S. and Lings, I. (2017), “Internal market orientation determinants of employee brand enactment”. Journal of Services Marketing, Vol. 31 No. 7, pp. 690-703. 
Boyatzis, R. E. (1998), Transforming Qualitative Information: Thematic Analysis and Code 28 Development, Thousand Oaks: SAGE.

Braun, V. and Clarke, V. (2006), "Using thematic analysis in psychology”. Qualitative Research in Psychology, Vol. 3 No. 2, pp. 77-101.

Buil, I., Martínez, E. and Matute, J. (2016), “From internal brand management to organizational citizenship behaviours: Evidence from frontline employees in the hotel industry". Tourism Management, Vol. 57 No. 2, pp. 256-271.

Burmann, C., Zeplin, S. and Riley, N. (2009), "Key determinants of internal brand management success: An exploratory empirical analysis". Journal of Brand Management, Vol. 16 No. 4, pp. 264-284.

Conduit, J., Matanda, M. J. and Mavondo, F. T. (2014), "Balancing the act: the implications of jointly pursuing internal customer orientation and external customer orientation", Journal of Marketing Management, Vol. 30 No. 13-14, pp. 1320-1352.

Cornelissen, J. (2017), Corporate communication: A guide to theory and practice, 5 th edn. London: Sage.

Danneels, E. (2011), “Trying to become a different type of company: Dynamic capability at Smith Corona", Strategic Management Journal, Vol. 32 No. 1, pp.1-31.

De Busy, N. M., Ewing, M. T. and Pitt, L. F. (2003), "Stakeholder theory and internal marketing communications: a framework for analysing the influence of new media". Journal of Marketing Communications, Vol. 9 No. 3, pp. 147-161.

Deloitte (2019), Annual Review of Football Finance. London: Deloitte. 
Desai, M.N., Lockett, A. and Paton, D. (2018), "Information asymmetries in the hiring process and the risk of new leader dismissal: insights from English Premier League soccer organizations". British Journal of Management, Vol. 29 No. 1, pp. 26-42.

Dolphin, R. R. (2005), “Internal Communications: Today's Strategic Imperative”. Journal of Marketing Communications, Vol. 11 No. 3, pp. 171-190.

Du Preez, R., Bendixen, M. and Abratt, R. (2017), "The behavioral consequences of internal brand management among frontline employees". Journal of Product \& Brand Management, Vol. 26 No. 3, pp. 251-261.

Forward, G.L., Czech, K. and Lee, C.M. (2011), “Assessing Gibb's supportive and defensive communication climate: An examination of measurement and construct validity". Communication Research Reports, Vol. 28 No. 1, pp. 1-15.

Frank, A. and Brownell, J. (1989), Organizational Communication and Behaviour: Communicating to Improve Performance. Orlando, FL: Holt, Rinehart and Winston.

Finney, S. and Scherrebeck-Hansen, M. (2010), “Internal marketing as a change management tool: A case study in re-branding". Journal of Marketing Communications, Vol. 16 No. 5, pp. 325-344.

Gerrard, B. and Lockett, A. (2018), "Team-specific Human Capital and Performance”. British Journal of Management, Vol. 29 No. 1, pp. 10-25.

Gibb, J. (1961), “Defensive communication”. Journal of Communication, Vol. 11, 141-148

Gibson, C.B. and Gibbs, J.L. (2006), “Unpacking the concept of virtuality: The effects of geographic dispersion, electronic dependence, dynamic structure, and national diversity on team innovation”. Administrative Science Quarterly, Vol. 51 No. 3, pp.451-495. 
Gurau, C. (2008), “Integrated online marketing communication: implementation and management". Journal of Communication Management, Vol. 12 No. 2, pp. 169-184.

Grosser, T.J., Lopez-Kidwell, V. and Labianca, G. (2010), “A social network analysis of positive and negative gossip in organizational life". Group \& Organization Management, Vol. 35 No. 2, pp. 177-212.

Grunig, L. A., Grunig, J. E. and Ehling, W. P. (1992), “What is an effective organization? ” In J. E. Grunig, D. M. Dozier, W. P. Ehling, L. A. Grunig, F. C. Repper, \& J. White (Eds.), Excellence in public relations and communication management (pp. 65-90). Hillsdale, NJ: Lawrence Erlbaum Associates, Inc.

Guzley, R. M. (1992), “Organizational climate and communication climate”. Management Communication Quarterly, Vol. 5 No. 4, pp. 379-402.

Harris, T.E. (1993), Applied Organizational Communication: Perspectives, Principles, and Pragmatics. New Jersey: Lawrence Erlbaum.

Homburg, C. and Jensen, O. (2007), "The thought worlds of marketing and sales: which differences make a difference?". Journal of Marketing, Vol. 71 No. 3, pp. 124-142.

Hughes, M., Hughes, P., Mellahi, K. and Guermat, C. (2010), "Short-term versus long-term impact of managers: evidence from the football industry". British Journal of Management, Vol. 21 No. 2, pp. 571-589.

Hunt, B. and Ivergard, T. (2007), "Organizational climate and workplace efficiency: learning from performance measurement in a public-sector cadre organization". Public Management Review, Vol. 9 No. 1, pp. 27-47. 
Judson, K. M., Gorchels, L. and Aurand, T. W. (2006), "Building a University Brand from Within: A Comparison of Coaches’ Perspectives of Internal Branding”. Journal of Marketing for Higher Education, Vol. 16 No. 1, pp. 97-114.

Kalla, H.A. (2005), "Integrated internal communications: a multidisciplinary perspective”. Corporate Communications: An International Journal, Vol. 10 No. 4, pp. 302-14.

Keller, K.L. (2016), “Unlocking the Power of Integrated Marketing Communications: How Integrated Is Your IMC Program?’. Journal of Advertising, Vol. 45 No. 3, pp. 286-301.

Kenyon, J. A., Manoli, A. E. and Bodet, G. (2018), "Brand consistency and coherency at the London 2012 Olympic Games”. Journal of Strategic Marketing, Vol. 26 No. 1, pp. 6-18.

King, C. (2010), “One size doesn't fit all.” International Journal of Contemporary Hospitality Management, Vol. 22 No. 4, pp. 517-534.

Kirby, J.R., Knapper, C.K., Evans, C.J., Carty, A.E. and Gadula, C. (2003), “Approaches to learning at work and communication climate". International Journal of Training and Development, Vol. 7 No. 1, pp. 31-52.

Kumar, N., Stern, L.W. and Anderson, J.C. (1993), “Conducting interorganizational research using key informants”. Academy of Management Journal, Vol. 36 No. 6, pp. 1633-1651.

Luxton, S., Reid, M. and Mavondo, F. (2017), "IMC Capability: antecedents and implications for brand performance”. European Journal of Marketing. Vol. 51 No. 3, pp. 421-444.

Malhotra, N. and Ackfeldt, A. L. (2016), “Internal communication and prosocial service behaviors of front-line employees: Investigating mediating mechanisms". Journal of Business Research, Vol. 69 No. 10, pp. 4132-4139.

Manoli, A. E. (2016), “Crisis-communications management in football clubs”. International Journal of Sport Communication, Vol. 9 No. 3, pp. 340-363. 
Manoli, A. E. (2017), Media relations in English football clubs. In J. J. Zhang \& B. G. Pitts (Eds.), Contemporary Sport Marketing (pp. 120-138). Oxon: Routledge.

Manoli, A. E. and Hodgkinson, I. R. (2017), "Marketing outsourcing in the English Premier League: the rights holder/agency interface”. European Sport Management Quarterly, Vol. 17 No. 4, pp. 436-456.

Matanda, M. J. and Ndubisi, N. O. (2013), "Internal marketing, internal branding, and organisational outcomes: The moderating role of perceived goal congruence". Journal of Marketing Management, Vol. 29 No. 9-1, pp. 1030-1055.

Martin, H.J. (2010), “Communication climate and peer support as determinants of training transfer”. Human Resource Development Quarterly, Vol. 21 No. 1, pp. 87-104.

Men, L. R. (2014), “Strategic internal communication: Transformational leadership, communication channels, and employee satisfaction". Management Communication Quarterly, Vol. 28 No. 2, pp. 264-284.

Morhart, F. M., Herzog, W. and Tomczak, T. (2009), “Brand-Specific Leadership: Turning Employees into Brand Champions”. Journal of Marketing, Vol. 73 No. 5, pp. 122-142.

Newman, A., Donohue, R. and Eva, N. (2017), "Psychological safety: A systematic review of the literature”. Human Resource Management Review, Vol. 27 No. 3, pp.521-535.

Nurmi, N. and Koroma, J. (2020), "The emotional benefits and performance costs of building a psychologically safe language climate in MNCs”. Journal of World Business, Vol. 55 No. 4, pp.1-15.

Piha, L. P. and Avlonitis, G. J. (2018), “Internal brand orientation: conceptualisation, scale development and validation”. Journal of Marketing Management, Vol. 34 No. 3-4, pp. 370-394. 
Punjaisri, K., Wilson, A. and Evanschitzky, H. (2008), “Exploring the Influences of Internal Branding on Employees’ Brand Promise Delivery: Implications for Strengthening Customer-Brand Relationships”. Journal of Relationship Marketing, Vol. 7 No. 4, pp. 407-424.

Quirke, M.B. (2012), Making the connections: using internal communication to turn strategy into action, 2nd edn. Aldershot, UK: Gower Publishing.

Ridder, J.A. (2004), “Organisational communication and supportive employees”. Human Resource Management Journal, Vol. 14 No. 3, pp. 20-30.

Ruck, K. and Welch, M. (2012), "Valuing internal communication; management and employee perspectives". Public Relations Review, Vol. 38 No. 2, pp. 294-302.

Simha, A. and Cullen, J.B. (2012), "Ethical climates and their effects on organizational outcomes: Implications from the past and prophecies for the future". Academy of Management Perspectives, Vol. 26 No.4, pp. 20-34.

Smidts, A., Pruyn, A. and van Riel, C. (2001), "The impact of employee communication and perceived external prestige on organizational identification". Academy of Management Journal, Vol. 49 No. 5, pp. 1051-62.

Starbuck, W.H. (2010), “What makes a paper influential and frequently cited?”. Journal of Management Studies, Vol. 47 No. 7, pp. 1394-1404.

Teece, D.J. (2014), “The foundations of enterprise performance: Dynamic and ordinary capabilities in an (economic) theory of firms". Academy of Management Perspectives, Vol. 28 No. 4, pp.328-352. 
Van Den Hooff, B. and De Ridder, J.A. (2004), "Knowledge sharing in context: the influence of organizational commitment, communication climate and CMC use on knowledge sharing". Journal of Knowledge Management, Vol. 8 No. 6, pp. 117-130.

Valos, M.J., Maplestone, V.L., Polonsky, M.J. and Ewing, M. (2017), “Integrating social media within an integrated marketing communication decision-making framework". Journal of Marketing Management, Vol. 33 No. 17-18, pp. 1522-1558.

Welch, M. and Jackson, P.R. (2007), "Rethinking internal communication: a stakeholder approach”. Corporate Communications: An International Journal, Vol. 12 No. 2, pp. 177-198.

Wright, D. (1995), “The role of corporate public relations executives in the future of employee communications". Public Relations Review, Vol. 21 No. 3, pp. 181-98.

Zsidisin, G.A., Hartley, J.L., Bernardes, E.S. and Saunders, L.W. (2015), “Examining supply market scanning and internal communication climate as facilitators of supply chain integration”. Supply Chain Management: An International Journal, Vol. 20 No. 5, pp. 549-560. 
Figure 1. Type 1 Data Audit

\section{First-Order Codes}

We have seamless communication among us and it's really important having this communication and mutual respect for each other and each other's job. There's a lot more we can do in order to engage staff as brand representatives, club advocates, more staff meetings, more interaction'(B)
Theoretical Categories

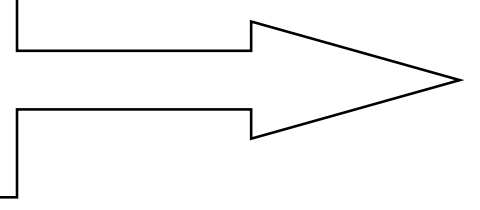

Cooperative

Interactions

'We talk to each other every day, multiple times a day.

Even though we're not in the same team, we're in constant communication, all the time. There's meetings and other things in place that make us be in this constant contact all the time'(R)

'It's nice working in such a club. I'm not really used to

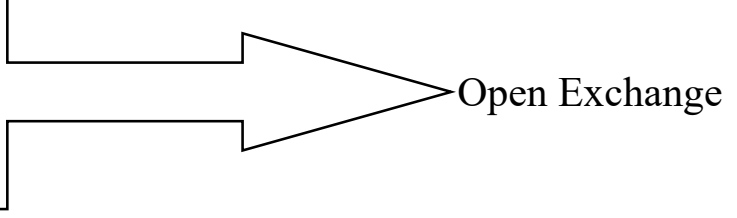

Aggregate Theoretical Dimension such a nice atmosphere in a workplace. We like each other, respect each other. We appreciate and are appreciated about our skills and job. We work together, ask for feedback and give feedback to our colleagues all the

'We're encouraged to talk and work together all the time. The open office helps, since it feels like we're all sitting together...Everyone encourages you to talk openly and we get all the chances to do it, there's meetings happening all the time and there's cross-over of workloads as well.' (R)

\section{L

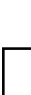
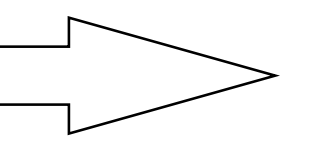

Support

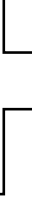

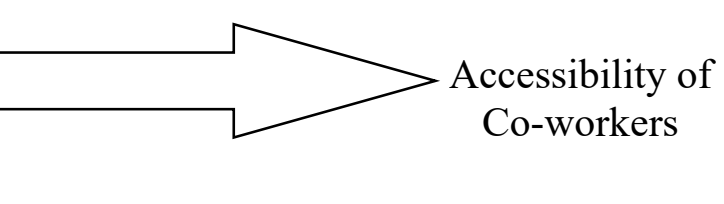

'We have to get it right every time for the club. It doesn't matter who writes the message, the sender is always the club and we have to get it right every time. We work closely to get it right and we're doing a great job at it' (AA)

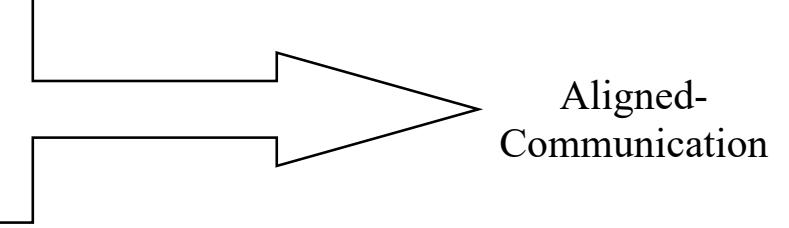

\section{Collaborative symmetrical communication \\ (Cohesive climate)}


Figure 2. Type 2 Data Audit

\section{First-Order Codes}

'It's really so easy to talk to each other directly. You go to their office, ask them something, get an opinion, give yours, exchange a few ideas and that's it. It's so easy to get things done when you talk face-to-face with someone...This direct idea runs through the club and it's what makes us all work so well with each other' $(\mathrm{N})$

'You have to talk all the time. A business like ours, 24-hoursa-day, 365-days-a-year, we must have an integrated approach with all key departments working closely together. We're sitting next to each other, so it's just so easy to grab each other and talk...We don't need fancy meetings and long emails. We follow a direct, face-to-face approach. Why get wordy (L)

'We have a pretty good relationship, not only with them but with everyone. It's a nice atmosphere in the club, nice, friendly. Being close to each other, sharing a cuppa on your break, it helps. We're direct with each other and that brings us closer.'(Y)

"We seize the moment, grab an opportunity and make sure we always make the best of what we have' $(\mathrm{O})$ 'Talking to each other and making sure that what we say sounds the same

throughout the club is vital for us... There's always someone coming and asking for my help and I go and ask them too. We sit a few feet from each other, so it's really easy'(C)

'We all pretty much get the brand around here, so I think we're doing a great job at it. But talking to each other, having this good relationship, directness and openness with each other helps. I mean, all anyone around here has to do is come and grab me and I'll help in getting the brand across in every message. It's this directness that helps us function that well'( $\mathrm{F})$
Theoretical Categories

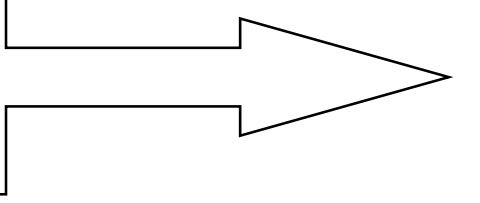

Direct

Interaction
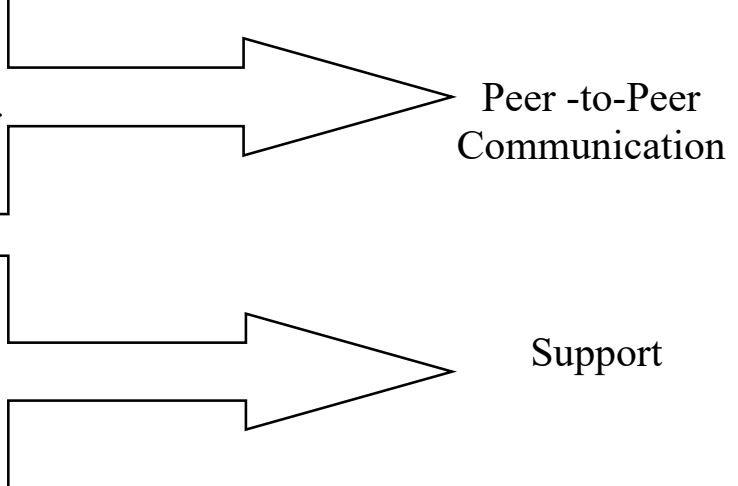

Support

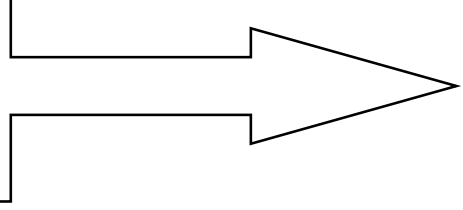

Responsive

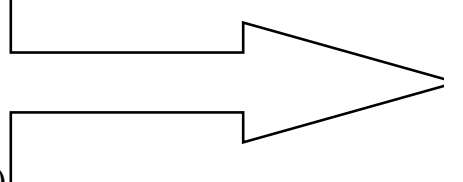

Aligned-

Communication
Aggregate Theoretical

Dimension

Unstructured informal

communication

(Friendly climate) 
Figure 3. Type 3 Data Audit

\section{First-Order Codes}

'We don't really interact unless there's something we need from each other.... Or to be honest, they ask us and we do it They come, they ask, we do. It's not really a dialogue or a long discussion, but a request, 'please write this for us'. We do it, we give it to them and that's it really' $(\mathrm{X})$

'We sit together, so it's easy to grab someone...However, we end up talking to each other only when there's something urgent for which we need each other's help'(M)

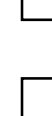

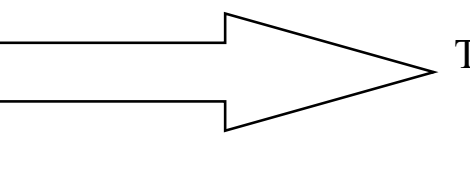

Transactional

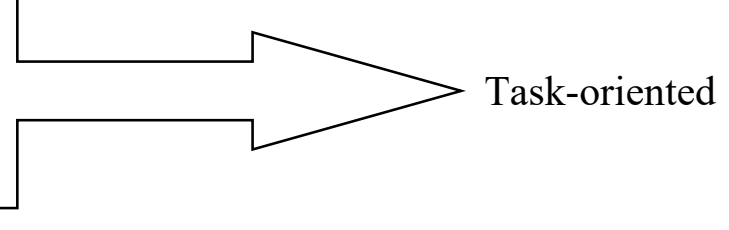

'I believe we're good at our job, and for that reason we need freedom to do it. I don't need them to tell me what to do. If I need them for something, I'll ask them...If I go in and micromanage others, give them my opinion about every single thing, that wouldn't help, would it?'(AC)

'I get what you mean about working together, but I don't really think that's necessary. We are separate, and we do our job separately and pretty well. I shouldn't be involved in how they do it, so why would I ask for their involvement?'(E)

'It depends on the message you're trying to get across to be honest. So, we might want to get the fans to come to the stadium and the commercial guys want to sell more sponsorships. That's not the same message, why should it sound the same. We each have our own tasks and we are good in getting our own message across'(P)

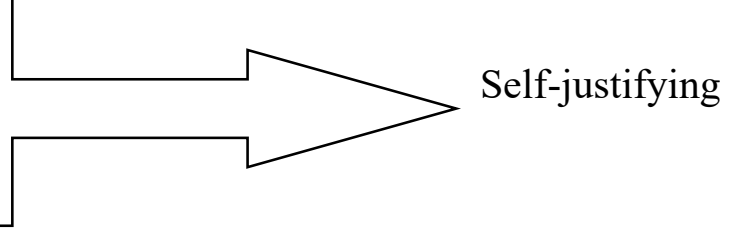

Cross-functional silos (Divisive climate) 
Table 1. An internal organisational communication typology

\begin{tabular}{|c|c|}
\hline $\begin{array}{c}\text { Internal Organisational } \\
\text { Communication Type }\end{array}$ & Type Characteristics \\
\hline $\begin{array}{l}\text { Type } 1 \text { Collaborative symmetrical } \\
\text { communication: Cohesive }\end{array}$ & $\begin{array}{l}\text { - Harmonised communication: formal and informal, upward, } \\
\text { - Cownward, \& horizontal } \\
\text { - Cross-functional communication is encouraged } \\
\text { - 'Oeekly meetings reinforce 'team' \& 'openness' } \\
\text { - Twon office' policy } \\
\text { - Consistent and coherent brand message }\end{array}$ \\
\hline $\begin{array}{l}\text { Type } 2 \text { Unstructured informal } \\
\text { communication: Friendly }\end{array}$ & $\begin{array}{l}\text { - Unstructured, symmetrical \& informal } \\
\text { - Informal methods of communication replace formal } \\
\text { - } \text { Frocedures } \\
\text { - A 'more direct' approach among employees } \\
\text { - Peer-to-peer communication can reduce traceability of } \\
\text { errors } \\
\text { - Longevity and continuity of outward- marketing } \\
\text { messaging is challenged }\end{array}$ \\
\hline $\begin{array}{l}\text { Type } 3 \text { Cross-functional silos: } \\
\text { Divisive }\end{array}$ & $\begin{array}{l}\text { - One-way, asymmetrical communication } \\
\text { - Forced, task-driven communication } \\
\text { - Absence of informal communication between functions } \\
\text { - Infrequent, formal cross-functional meetings } \\
\text { - Physical separation of marketing and media functions } \\
\text { - 'Internal functional silos' } \\
\text { - Co-ordination of outward communication is obstructed }\end{array}$ \\
\hline
\end{tabular}


Appendix A. Respondents and organisational information

\begin{tabular}{|c|c|c|c|c|c|c|}
\hline Club & Seniority & Department & $\begin{array}{l}\text { Interview } \\
\text { length }\end{array}$ & $\begin{array}{l}\text { Marketing \& } \\
\text { media } \\
\text { functions }\end{array}$ & $\begin{array}{l}\text { Marketing } \\
\& \text { media } \\
\text { employees }\end{array}$ & $\begin{array}{l}\text { Communication } \\
\text { type }\end{array}$ \\
\hline $\bar{A}$ & $\begin{array}{l}\text { Head of } \\
\text { department }\end{array}$ & $\begin{array}{l}\text { Marketing } \\
\text { and media }\end{array}$ & $65 \mathrm{~min}$ & One department & 6 & Type 3 \\
\hline B & $\begin{array}{l}\text { Head of } \\
\text { department }\end{array}$ & $\begin{array}{l}\text { Marketing } \\
\text { and media }\end{array}$ & $67 \mathrm{~min}$ & One department & 6 & Type 1 \\
\hline $\mathrm{C}$ & $\begin{array}{l}\text { Head of } \\
\text { department }\end{array}$ & Marketing & $72 \mathrm{~min}$ & $\begin{array}{l}\text { Separate } \\
\text { departments }\end{array}$ & 7 & Type 2 \\
\hline $\mathrm{D}$ & $\begin{array}{l}\text { Head of } \\
\text { department }\end{array}$ & Marketing & $64 \mathrm{~min}$ & $\begin{array}{l}\text { Separate } \\
\text { departments }\end{array}$ & 6 & Type 3 \\
\hline $\mathrm{E}$ & $\begin{array}{l}\text { Middle } \\
\text { management }\end{array}$ & Media & $78 \mathrm{~min}$ & $\begin{array}{l}\text { Separate } \\
\text { departments }\end{array}$ & 6 & Type 3 \\
\hline $\mathrm{F}$ & $\begin{array}{l}\text { Middle } \\
\text { management }\end{array}$ & Marketing & $80 \mathrm{~min}$ & $\begin{array}{l}\text { Separate } \\
\text { departments }\end{array}$ & 5 & Type 2 \\
\hline G & $\begin{array}{l}\text { Head of } \\
\text { department }\end{array}$ & Media & $64 \mathrm{~min}$ & $\begin{array}{l}\text { Separate } \\
\text { departments }\end{array}$ & 2 & Type 3 \\
\hline $\mathrm{H}$ & $\begin{array}{l}\text { Head of } \\
\text { department }\end{array}$ & Marketing & $60 \mathrm{~min}$ & $\begin{array}{l}\text { Separate } \\
\text { departments }\end{array}$ & 4 & Type 3 \\
\hline I & $\begin{array}{l}\text { Middle } \\
\text { management }\end{array}$ & Media & $67 \mathrm{~min}$ & $\begin{array}{l}\text { Separate } \\
\text { departments }\end{array}$ & 9 & Type 3 \\
\hline $\mathrm{J}$ & $\begin{array}{l}\text { Middle } \\
\text { management }\end{array}$ & Marketing & $50 \mathrm{~min}$ & $\begin{array}{l}\text { Separate } \\
\text { departments }\end{array}$ & 4 & Type 2 \\
\hline K & $\begin{array}{l}\text { Middle } \\
\text { management }\end{array}$ & Marketing & $48 \mathrm{~min}$ & $\begin{array}{l}\text { Separate } \\
\text { departments }\end{array}$ & 6 & Type 3 \\
\hline $\mathrm{L}$ & $\begin{array}{l}\text { Head of } \\
\text { department }\end{array}$ & Media & $72 \mathrm{~min}$ & $\begin{array}{l}\text { Separate } \\
\text { departments }\end{array}$ & 10 & Type 2 \\
\hline M & $\begin{array}{l}\text { Head of } \\
\text { department }\end{array}$ & Media & $64 \mathrm{~min}$ & $\begin{array}{l}\text { Separate } \\
\text { departments }\end{array}$ & 16 & Type 3 \\
\hline $\mathrm{N}$ & $\begin{array}{l}\text { Head of } \\
\text { department }\end{array}$ & Marketing & $60 \mathrm{~min}$ & $\begin{array}{l}\text { Separate } \\
\text { departments }\end{array}$ & 8 & Type 2 \\
\hline $\mathrm{O}$ & $\begin{array}{l}\text { Head of } \\
\text { department }\end{array}$ & Marketing & $62 \mathrm{~min}$ & $\begin{array}{l}\text { Separate } \\
\text { departments }\end{array}$ & 8 & Type 2 \\
\hline $\mathrm{P}$ & $\begin{array}{l}\text { Head of } \\
\text { department }\end{array}$ & Media & $65 \mathrm{~min}$ & $\begin{array}{l}\text { Separate } \\
\text { departments }\end{array}$ & 9 & Type 3 \\
\hline Q & $\begin{array}{l}\text { Head of } \\
\text { department }\end{array}$ & $\begin{array}{l}\text { Marketing } \\
\text { and media }\end{array}$ & $63 \mathrm{~min}$ & One department & 11 & Type 1 \\
\hline $\mathrm{R}$ & $\begin{array}{l}\text { Head of } \\
\text { department }\end{array}$ & Media & $66 \mathrm{~min}$ & $\begin{array}{l}\text { Separate } \\
\text { departments }\end{array}$ & 19 & Type 1 \\
\hline $\mathrm{S}$ & $\begin{array}{l}\text { Middle } \\
\text { management }\end{array}$ & $\begin{array}{l}\text { Marketing } \\
\text { and media }\end{array}$ & $58 \mathrm{~min}$ & One department & 2 & Type 3 \\
\hline $\mathrm{T}$ & $\begin{array}{l}\text { Head of } \\
\text { department }\end{array}$ & Marketing & $74 \mathrm{~min}$ & $\begin{array}{l}\text { Separate } \\
\text { departments }\end{array}$ & 4 & Type 3 \\
\hline $\mathrm{U}$ & $\begin{array}{l}\text { Head of } \\
\text { department }\end{array}$ & Marketing & $66 \mathrm{~min}$ & $\begin{array}{l}\text { Separate } \\
\text { departments }\end{array}$ & 2 & Type 3 \\
\hline V & $\begin{array}{l}\text { Head of } \\
\text { department }\end{array}$ & Marketing & $62 \mathrm{~min}$ & $\begin{array}{l}\text { Separate } \\
\text { departments }\end{array}$ & 12 & Type 1 \\
\hline W & $\begin{array}{l}\text { Head of } \\
\text { department }\end{array}$ & Media & $61 \mathrm{~min}$ & $\begin{array}{l}\text { Separate } \\
\text { departments }\end{array}$ & 5 & Type 3 \\
\hline
\end{tabular}




\begin{tabular}{|c|c|c|c|c|c|c|}
\hline $\mathrm{X}$ & $\begin{array}{l}\text { Head of } \\
\text { department }\end{array}$ & Marketing & $59 \mathrm{~min}$ & $\begin{array}{l}\text { Separate } \\
\text { departments }\end{array}$ & 13 & Type 3 \\
\hline $\mathrm{Y}$ & $\begin{array}{l}\text { Head of } \\
\text { department }\end{array}$ & Media & $70 \mathrm{~min}$ & $\begin{array}{l}\text { Separate } \\
\text { departments }\end{array}$ & 11 & Type 2 \\
\hline Z & $\begin{array}{l}\text { Middle } \\
\text { management }\end{array}$ & Marketing & $72 \mathrm{~min}$ & $\begin{array}{l}\text { Separate } \\
\text { departments }\end{array}$ & 2 & Type 3 \\
\hline AA & $\begin{array}{l}\text { Head of } \\
\text { department }\end{array}$ & Marketing & $62 \mathrm{~min}$ & $\begin{array}{l}\text { Separate } \\
\text { departments }\end{array}$ & 24 & Type 1 \\
\hline $\mathrm{AB}$ & $\begin{array}{l}\text { Middle } \\
\text { management }\end{array}$ & Media & $58 \mathrm{~min}$ & $\begin{array}{l}\text { Separate } \\
\text { departments }\end{array}$ & 11 & Type 2 \\
\hline $\mathrm{AC}$ & $\begin{array}{l}\text { Middle } \\
\text { management }\end{array}$ & $\begin{array}{l}\text { Marketing } \\
\text { and media }\end{array}$ & $60 \mathrm{~min}$ & One department & 5 & Type 3 \\
\hline $\mathrm{AD}$ & $\begin{array}{l}\text { Head of } \\
\text { department }\end{array}$ & Marketing & $61 \mathrm{~min}$ & $\begin{array}{l}\text { Separate } \\
\text { departments }\end{array}$ & 12 & Type 3 \\
\hline $\mathrm{AE}$ & $\begin{array}{l}\text { Head of } \\
\text { department }\end{array}$ & $\begin{array}{l}\text { Marketing } \\
\text { and media }\end{array}$ & $70 \mathrm{~min}$ & One department & 3 & Type 3 \\
\hline $\mathrm{AF}$ & $\begin{array}{l}\text { Middle } \\
\text { management }\end{array}$ & $\begin{array}{l}\text { Marketing } \\
\text { and media }\end{array}$ & $75 \mathrm{~min}$ & One department & 4 & Type 2 \\
\hline $\mathrm{AG}$ & $\begin{array}{l}\text { Middle } \\
\text { management }\end{array}$ & Marketing & $74 \mathrm{~min}$ & $\begin{array}{l}\text { Separate } \\
\text { departments }\end{array}$ & 6 & Type 1 \\
\hline
\end{tabular}




\section{Appendix B. Sample of interview questions}

- Where does Marketing and Communications/Media fit within the organisation?

a. Could you describe the relationship between the two teams?

b. Would you say you work well together?

c. Do you operate as a team or as two separate teams?

d. Do you feel there is a good relationship between you?

- Have there been any problems between the two teams?

a. How were they resolved?

- What is your relationship with other departments?

- Is there anyone from the higher administration of the club involved in Marketing and Communications/Media?

a. Is there a marketing communications/media strategy?

b. Is there a separate marketing and a separate communications/media strategy?

c. Who manages what?

- What about involvement from other departments?

a. Is this a collaboration? How does it work?

b. Do you organise meetings with the other departments regarding marketing and communications/media issues?

c. Who is involved?

d. Do you coordinate these meetings?

- Is there an internal communications plan?

a. Can you give me details about it?

b. Who manages it?

- Do you think that the relationship Marketing and Media employees have with each other is representative of the relationship among all employees within the club?

a. What could improve overall? 